\title{
The Strategies in Strengthening the Role of Zakat Boards and Institutions in Indonesia
}

\author{
Qurroh Ayuniyyah, Didin Hafidhuddin \\ Postgraduate School, Bogor Ibn Khaldun University \\ Hambari \\ Faculty of Islamic Studies, Bogor Ibn Khaldun University
}

\begin{abstract}
This study attempts to formulate strategies in strengthening the role of zakat boards and institutions in Indonesia from the perspectives of three zakat experts and practitioners by employing Analytical Network Process (ANP) method. While the indicators of zakat institutions' performance measured in this study are based on the National Zakat Indices (abbreviated as NZI), the alternatives of strategy are constructed through study of literatures. This study suggests that among four zakat institutions' indicators, the reporting of zakat shared the highest portion of the important indicators of amil's performance, followed by the collection, distribution and management of zakat. Besides, the study also finds the strategies that need to be given top priorities based on their orders, including; optimizing zakat distribution program, strengthening Information and Technology (IT) system, strengthening zakat regulation, improving database of zakat payers and beneficiaries, strengthening the synergy between zakat boards, institutions and other zakat stakeholders, strengthening human resources and improving socialization as well as education pertaining to zakat and the role of zakat boards and institutions.
\end{abstract}

Keywords: Zakat; Amil Board and Institutions; ANP

\section{INTRODUCTION}

As the third pillar of Islam, zakat plays a vital role not only from the perspective of religion, but also from the socio-economic point of views. As such, zakat has the role to alleviate poverty and to reduce inequality among society as mentioned in the Quran 9: 60 and the Quran 59: 7.

The function of zakat for both aspects can be realized if zakat boards and institutions (amil) as assigned in the Quran 9: 103 are able to strengthen its position in collecting, managing and distributing zakat fund in the society. This occurred in the period of the Caliphate of Umar bin Abdul Aziz. When zakat was managed in the hand of strong and professional amil, zakat was able to solve socio-economic problems specifically the dual problems of poverty and income inequality (Syahhatih, 1989). This shows that it is vital to have transparent and reliable amil.

Hafidhuddin et al (2015) argue that there are five advantages if zakat collection and distribution process are managed by amil. First, this practice is in line with shariah guideline including Al-Quran, hadith as well as the examples given by the companions of Rasulullah (s.a.w). Second, amil institutions can ensure the discipline of zakat payers to fulfill their obligations. Third, amil institutions can protect the dignity of zakat recipients. Forth, the management of zakat is likely to be more efficient and effective through amil institutions. Fifth, the professional amil institutions can apply the modern indirect financial system. 
In Indonesia, the National Zakat Board (abbreviated as BAZNAS) was established based on presidential decree No. $21 / 2001^{1}$ as the coordinating zakat institution at the national level (Hafidhuddin, 2015). One of important tasks of BAZNAS is to realize the high potential for zakat collection in Indonesia. A study done by Firdaus et al (2012) shows that the national zakat potential collection is USD 22.33 billion $^{2}$ per annum ${ }^{3}$ which approximately equals to 3.4 percent of the total GDP of Indonesia (vide Table 1.1).

It appears that private industry contributes the largest portion with more than a half of total collection, followed by household with approximately one third. The remaining 10 percent is contributed by saving and state-owned enterprises. This is evident from figures in column (2) of Table 1.1 .

This high potential of zakat collection might be due to the high Muslim population in Indonesia. According to Pew Research Center (2010), Indonesia constitutes the largest Muslim population in the world that shares 12.7 percent of the world's Muslims followed by Pakistan (11 percent), India (10.9 percent) and Bangladesh (10 percent).

Table 1.1. Potential zakat collection in Indonesia per annum

\begin{tabular}{ccc}
\hline Description & $\begin{array}{c}\text { Potential } \\
\text { Zakat }\end{array}$ & $\begin{array}{c}\text { Percentage of } \\
\text { GDP }(\%) \\
\text { Collection }\end{array}$ \\
& $(1)$ \\
(USD & \\
billion) &
\end{tabular}

${ }^{1}$ After 12 years of implementation, Zakat Management Act No 23/2011 replaced the previous Act with some vital alterations such as, strengthening the role of BAZNAS and fostering the synergy and collaboration between BAZNAS and
(1)

\begin{tabular}{lll}
\hline $\begin{array}{l}\text { Private } \\
\text { Industry }\end{array}$ & 11.82 & 1.80 \\
Household & 8.54 & 1.30 \\
Saving & 1.77 & 0.27 \\
State & 0.20 & 0.03 \\
$\begin{array}{l}\text { Owned } \\
\text { Enterprises }\end{array}$ & \\
\hline Total & 22.33 & 3.40 \\
\hline \multicolumn{2}{l}{ Source: Firdaus et al (2012) }
\end{tabular}

Table 1.2. National zakat collection, 20022015

\begin{tabular}{ccc}
\hline Year & $\begin{array}{c}\text { Total Zakat } \\
\text { Collection } \\
\text { (USD } \\
\text { million) }\end{array}$ & $\begin{array}{c}\text { Annual } \\
\text { Growth }\end{array}$ \\
\hline 2002 & 5.47 & - \\
2003 & 6.82 & 24.70 \\
2004 & 12.00 & 76.00 \\
2005 & 23.64 & 96.90 \\
2006 & 29.85 & 26.28 \\
2007 & 59.19 & 98.30 \\
2008 & 73.59 & 24.32 \\
2009 & 95.98 & 30.43 \\
2010 & 119.98 & 25.00 \\
2011 & 138.38 & 15.25 \\
2012 & 175.97 & 27.24 \\
\hline
\end{tabular}

other private zakat institutions (Hafidhuddin et al, 2015).

\footnotetext{
${ }^{2}$ Based on Central Bank of Indonesia in 28 December 2012, USD 1 equals to Rp9,718.

${ }^{3}$ The calculation of the potential zakat collection is presented in Appendix 3.
} 


\begin{tabular}{ccc}
\hline 2013 & 215.97 & 22.73 \\
2014 & 263.96 & 22.22 \\
2015 & 337.55 & 21.21 \\
\hline Average & 113.31 & 39.78 \\
\hline Notes: Based on Central Bank of Indonesia \\
data in 31 December 2014, USD 1 \\
equals to Rp12,502.
\end{tabular}

Source: BAZNAS Annual Report (2016)

Unfortunately, even zakat institution has been collaborating with fintech firms for zakat collection (Hudaefi, et. al, 2020), such actual collection of zakat fund still falls behind its notable potential. The latest collection of zakat was only roughly 3 percent of its potential (vide Table 1.2). It suggests that greater endeavor to collect zakat should be prioritized, although the trend of zakat collection increases over the year. In Table 1.2 above, it is interesting to observe that there has been an upward trend of the national zakat collection by approximately 60 folds in the last decade. This shows that the awareness of the Muslims to fulfill the obligation of paying zakat is likely to rise. It appears that the growth of the fund collection reached a nearly 100 percent of annual growth in 2005 and 2007 when natural calamities hit the country. There were tsunami calamity in Aceh in 2005 and an earthquake in Yogyakarta two years after.

Despite the huge gap between the realization of zakat and its expectation as evident from Table 1.1 and 1.2, the current zakat distribution program has been empirically successful in helping lessen poverty and income gap among the society. For instance, Indonesia Zakat and Development Report (2012) shows that zakat is able to reduce the poverty incidence of mustahik by 21.11 percent in the year 2011. This finding is also supported by Beik (2013), which suggests that productive-based zakat distribution and free-hospital program can lower the poverty incidence in Jakarta.

Besides collection and distribution, the role of zakat boards and institutions is also important in managing and reporting zakat fund. Zakat management as stated in the Zakat Management Act No 23/2011 aspires to achieve two objectives. First, it aims at improving effectiveness and efficiency of zakat management service specifically with respect to zakat collection and distribution. Second, it purposes to strengthen the role of zakat to realize the welfare of the society as well as to eradicate poverty and income inequality. In this case, amil zakat must be trustable and hence the reporting of zakat must be also done to realize the transparency and professionalism of amil zakat. These four indicators, namely collection, distribution, management and reporting of zakat hence become the evaluation measures for institutional zakat performance that construct National Zakat Index (NZI) at the micro level published by BAZNAS in 2017.

Having known the important position of zakat boards and institutions, this paper attempts to formulate strategy in strengthening this role from the perspectives of zakat experts and practitioners in Indonesia. This paper comprises five sections including introduction in section one. Section two is the literature review followed by method as well as result and analysis in section three and four. Section five concludes.

\section{LITERATURE REVIEW}

Basic Concept of Zakat 
According to Al-Qaradawi (1993), zakat is defined as "the determined share of wealth prescribed by God to be distributed among deserving categories and is also used to mean the action of payment of this share." The importance of zakat can be seen from the twenty-seven verses among thirty-three verses in the Quran stating that the obligation of zakat is associated with prayer in various words.

Al-Qaradawi explains that the benefit of zakat is not only for the individual but also for the society. For the individual, zakat can elevate the spirit of human beings above the love of material acquisition and liberates the beneficiaries from material needs. This can minimize jealousy and hatred among people. For the society, zakat serves important social objectives as Islam's social insurance system and can realize spiritual integrity of the nation. These advantages make zakat plays a significant role in the development of the Muslim community.

The Quran 9: 60 mentions zakat beneficiaries are classified into categories (asnaf) namely, the poor (fuqara), the needy (masakin), zakat collectors (amilin), those newly converted to Islam (muallaf), ransoming of slaves (riqab), the debtors (al-gharimin), in the cause of Allah ( $f i$ sabilillah) and the wayfarers (ibnu sabil).

Al-Qaradawi (1993) argues that among the eight categories, the poor and the needy are the most important as it is in line with the ultimate goal of zakat. The distribution of zakat among the eight categories needs not to be equal depending on the total of zakat collection and the priorities of the aforementioned categories. Similarly, Sadeq (2002) finds that zakat helps lower poverty that brings untold sufferings. Poverty encourages begging, which is condemned by Islam.
According to Hasan (2006), zakat is an element that ranks third among the five fundamentals of Islam. The determination of the minimum limits beyond which zakat would be payable on different categories of wealth and its corresponding rate were left to the discretion of the Rasulullah (s.a.w). There are few characteristics of zakat that are as follows. First, the coverage of zakat is vast. It applies to both the incomes of certain types such as agricultural earnings and the wealth of the rich. Second, zakat is neither a tax nor charity. It cannot be abolished by an act of state, its rate cannot be altered and the amount collected can only be spent on specified heads. Zakat is the right of the poor and the needy to a share in the wealth of the rich that they have to part as believers.

In order to achieve the objectives of zakat, Hafidhuddin and Juwaini (2006) highlight the important role of amil institution for zakat management that is in line with the Quran 9: 60 and 103. They suggest that the role of amil institution is not only for zakat collection but also for zakat distribution as well as assessment.

According to the fatwa of Indonesian Ulama Council (abbreviated as MUI) No. $8 / 2011$, amil refers to a person or a group of people that are appointed by the government or society and get endorsement from the government to be responsible in managing zakat in the country. Hafidhuddin et al (2015) argue that amil is the intermediary between zakat payers and beneficiaries that should be trustable, transparent, professional and full-time assigned.

It is interesting to note that, the success of zakat in achieving its socioeconomic goals cannot be separated with the role of Islamic scholars and zakat experts. In this regard, Abdullah and Yusop (2015) highlight that zakat will be an 
effective tool to eradicate poverty if the two pre-requisites are satisfied. First, Islamic jurisprudence experts should endeavor a new and more reliable consensus pertaining to zakat. Second, Muslim bureaucrats should create a more dynamic and efficient zakat management system. In other words, the two conditions require a good collaboration between Islamic scholars, leaders and other zakat stakeholders to come up with overall zakat management based on zakatable income, assets and wealth that is applicable with the complexity of contemporary economics and business practices. This shows the important cooperation between all zakat stakeholders to build zakat as a system.

\section{Empirical Studies}

Perhaps, the study in formulating strategies to strengthen the position of amil institutions in Indonesia from the point of views of zakat experts and practitioners is still limited. The majority of existing empirical studies are based on the perspectives of either zakat payers or zakat recipients.

For instance, Shalihati (2010) conducts a specific field on muzakki's (zakat payers) perception towards BAZNAS and other amil institutions. She finds that all dimensions of marketing mix including product, price, place, promotion, people, process and physical evidence, significantly contribute in influencing perception and attitude.

Ayuniyyah and Shalihati (2011) analyze factors affecting muzakki to pay zakat through the institutions by taking case study of BAZNAS. In that study, 200 respondents are analyzed using binary regression model. The result shows that from expectation of muzakki, there are three factors that are positively affecting muzakki to pay zakat through amil institution including the strategic location, professionalism of amil officers and reporting of zakat program. These three factors should be maintained in order to increase the awareness of muzakki to pay zakat through amil.

However, there are also three expectation factors that negatively relate to the zakat payment through amil, i.e. zakat distribution, knowledge of amil about zakat and government certificate. The respondents expect that those factors have not been fulfilled well their expectation. This exhibits that amil should improve, repair and elevate these three factors to build muzakki's awareness.

To develop her previous study, Ayuniyyah (2011) analyzes the respondents using different method namely Importance Performance Analysis (IPA) to determine factors that needs to be improve by amil institutions to strengthen its position. She found that promotion program (socialization) and the ability of promotion program to trigger muzakki's curiosity to learn about zakat through amil institution should be improved. Muzakki are of the view that the promotion of BAZNAS and other institutions are still less attractive, thus they are not interested enough to learn about the advantage of paying zakat through amil institution.

An effort to formulate strategies from the point of view of practitioners of one private zakat institution is done by Rukmana (2014). From TOWS matrix, he suggests that the utilization of Information and Communication Technology (ICT) and strengthening internal management of the organization should be undertaken. The latter particularly should focus on the innovative zakat program as well as transparent and accountable zakat management. 


\section{METHODOLOGY}

\section{Types and Sources of Data}

This study employs primary data that is acquired through survey using questionnaire. The respondents are three zakat experts and practitioners in Indonesia. They are selected based on their competency, ability and deep understanding pertaining to zakat.

\section{Analytical Method}

This study uses the Analytical Network Process (ANP) in order to capture the view and opinion of zakat experts and practitioners to formulate the strategies in strengthening amil institutions in Indonesia. Saaty (1999) defines the Analytical Network Process (ANP) as "a general theory of a relative measurement used to derive composite priority ratio scales from individual ratio scales that represent relative measurements of the influence of elements that interact with respect to control criteria". It has the ability to capture the outcome of dependence and feedback within and between clusters of elements.

Saaty and Vargas (2006) explain that in general the ANP has four axioms as its theoretical bases that are as follows.

a. Reciprocal. This axiom states if PC (EA, EB) is a pairwise comparison from elements of $\mathrm{A}$ and $\mathrm{B}$, from the perspective of upper element of C. For instance, if $\mathrm{A}$ is three times larger than $\mathrm{B}$, then $\mathrm{B}$ is one third of $\mathrm{A}$.

b. Homogeneity. This axiom means that the elements being compared should not have large difference that may lead to biasness in determining the assessment of supporting elements, which influence the decisions.

c. Priority. This axiom refers to the absolute weight using interval scale
[0.1] and as relative domination measures.

d. Dependence condition. This axiom assumes the order can be composited into components that build cluster. The fundamental scale for making judgments can be found in Table 3.1.

Table 3.1. The fundamental scale for making judgments

\begin{tabular}{|c|c|}
\hline Definition & $\begin{array}{l}\text { Intensity of } \\
\text { Importance }\end{array}$ \\
\hline Equal & 1 \\
\hline $\begin{array}{c}\text { Between Equal and } \\
\text { Moderate }\end{array}$ & 2 \\
\hline Moderate & 3 \\
\hline $\begin{array}{c}\text { Between Moderate and } \\
\text { Strong }\end{array}$ & 4 \\
\hline Strong & 5 \\
\hline $\begin{array}{l}\text { Between Strong and } \\
\text { Very Strong }\end{array}$ & 6 \\
\hline Very Strong & 7 \\
\hline $\begin{array}{l}\text { Between Very Strong } \\
\text { and Extreme }\end{array}$ & 8 \\
\hline Extreme & 9 \\
\hline
\end{tabular}

Source: Saaty and Vargas (2006)

With regard to the steps of research, the ANP consists of three general steps that are as follows.

a. Model construction. This step is a crucial part that is done through literature review of both theoretical as well as empirical frameworks. Besides that, in-depth interview with the experts and focus group discussion can also be executed to gain deeper knowledge and information. In this study, the model is constructed through literature review and in-depth interview with one zakat expert. 
b. Model quantification. In this stage, the model constructed in the previous step is built into ANP questionnaire that consists of pairwise comparison between elements in the cluster so that we can know which one is more dominant in numeric scale from 1 to 9 (vide Table 3.1).

c. Synthesis and Analysis. This stage consists of two parts including geometric mean and rater agreement. Saaty and Vargas (2006) explain geometric mean is used to get individual judgments in the form of pairwise comparison so that we can have consensus between the respondents. According to Ascarya (2011), the formula of the geometric mean is as follows.

$$
\begin{aligned}
& \left(\pi_{i}^{n}=1 a_{i}\right)^{1 / n} \\
& =\sqrt[n]{a_{1} a_{2} \ldots a_{n}}
\end{aligned}
$$

Rater agreement refers to the ratio that shows compatibility (agreement) of the respondents about elements in the cluster. Kendall's coefficient of concordance is used to measure rate agreement. The value of the coefficient ranges from 0 to 1 where 1 shows perfect agreement (Ascarya, 2011).

\section{RESULTS AND ANALYSIS}

\section{Model Construction}

According to the National Zakat Index (2017), the performance indicators of zakat boards and institutions consist of four aspects including the collection, management, distribution and reporting of zakat. These four indicators become elements that construct criteria cluster at the top level. The four elements have also been validated through interview with the expert.

The collection of zakat refers to the ability and responsibility of amil zakat to collect zakat fund from zakat payers including its year on year growth. The management of zakat refers to the availability of standard operational procedures of zakat management, strategic planning, ISO certification or quality management and the annual working program. The distribution of zakat includes the allocation to collection ratio and the assessment on the economic program (productive-based program), social program and da'wah program. The reporting of zakat refers to the ability of zakat institutions to provide financial report with some audited standards.

The criteria of strategies to strengthen the aforementioned institutional indicators are based on Hafidhuddin et al (2015). They opine that there are several national zakat agenda that should be undertaken that are as follows.

a. Improving the socialization and education. This includes campaign to the society pertaining to definition, wisdom, benefit, object and regulation of zakat through variety of media. In this case, amil has an important position to optimize the role of zakat in aiming the welfare of the society.

b. Strengthening the institutions of zakat. This includes strengthening human resources, information and technology (IT) system of zakat and completing database of zakat payers and recipients.

c. Optimizing zakat program. This should be based on the comprehensive, integrated and updated database of zakat payers and recipients as well as the even standard operational procedures of zakat program management.

d. Strengthening the regulation of zakat. This includes the implementation of Zakat Management Act No. 23/2011 in order to achieve good amil governance (abbreviated as GAG).

e. Strengthening the synergy between all zakat stakeholders. This aspires to 
achieve harmony between zakat stakeholders and in the long run it is expected to build brotherhood among Muslim in Indonesia and in the world.

\section{Model Quantification}

According to the aforesaid model construction, the next stage is model quantification using the ANP model (vide Figure 4.1). Basically, the ANP in this study consists of two clusters.

The first cluster is the criteria of institutional performance indicators that consist of four elements including collection, management, distribution and reporting of zakat.

The second cluster is the alternatives that contain seven strategies in strengthening the amil institutions including improving the socialization and education, optimizing zakat program, strengthening human resources, strengthening zakat regulation, strengthening the database of muzakki and mustahik, strengthening the IT system and improving the synergy between zakat stakeholders.

\section{SYNTHESIS AND ANALYSIS}

Assessment of Criteria

According to the zakat experts' and practitioners' judgments as seen in Table 4.1 and Figure 4.2 below, reporting of zakat share the highest portion of criteria that construct the performance of amil institution followed by zakat collection, zakat distribution and zakat management in order. However, it is interesting to note that each element shares more than 20 percent to the total performance indicators implying that the portion of four elements only have slight differences.

\begin{tabular}{|c|c|c|c|}
\hline \multicolumn{4}{|c|}{ CRITERIA } \\
\hline $\begin{array}{c}\text { Collection of } \\
\text { Zakat }\end{array}$ & $\begin{array}{c}\text { Distribution of } \\
\text { Zakat }\end{array}$ & $\begin{array}{c}\text { Management of } \\
\text { Zakat }\end{array}$ & $\begin{array}{c}\text { Reporting of } \\
\text { Zakat }\end{array}$ \\
\hline
\end{tabular}

\begin{tabular}{|c|c|c|c|c|c|c|}
\hline \multicolumn{7}{|c|}{ ALTERNATIVES } \\
\hline $\begin{array}{c}\text { Socialization } \\
\text { and } \\
\text { Education }\end{array}$ & $\begin{array}{c}\text { Database } \\
\text { of Zakat } \\
\text { Payers } \\
\text { and } \\
\text { Recipients }\end{array}$ & $\begin{array}{c}\text { Optimization } \\
\text { Zakat } \\
\text { Program }\end{array}$ & $\begin{array}{c}\text { Human } \\
\text { Resources }\end{array}$ & Synergy & $\begin{array}{c}\text { Zakat } \\
\text { Regulation }\end{array}$ & $\begin{array}{c}\text { IT } \\
\text { System }\end{array}$ \\
\hline
\end{tabular}

Source: Author's Own

Figure 4.1. ANP Network 
Table 4.1. Assessment of Criteria

\begin{tabular}{lccccc}
\hline \multicolumn{1}{c}{ Criteria } & Respondent 1 & Respondent 2 & Respondent 3 & Average & Rank \\
\hline Report & 0.27496 & 0.31793 & 0.20872 & 0.26720 & 1 \\
Management & 0.19365 & 0.24427 & 0.25238 & 0.23010 & 4 \\
Collection & 0.27776 & 0.24012 & 0.28357 & 0.26715 & 2 \\
Distribution & 0.25364 & 0.19768 & 0.25532 & 0.23555 & 3 \\
\hline
\end{tabular}

Source: Author's Own

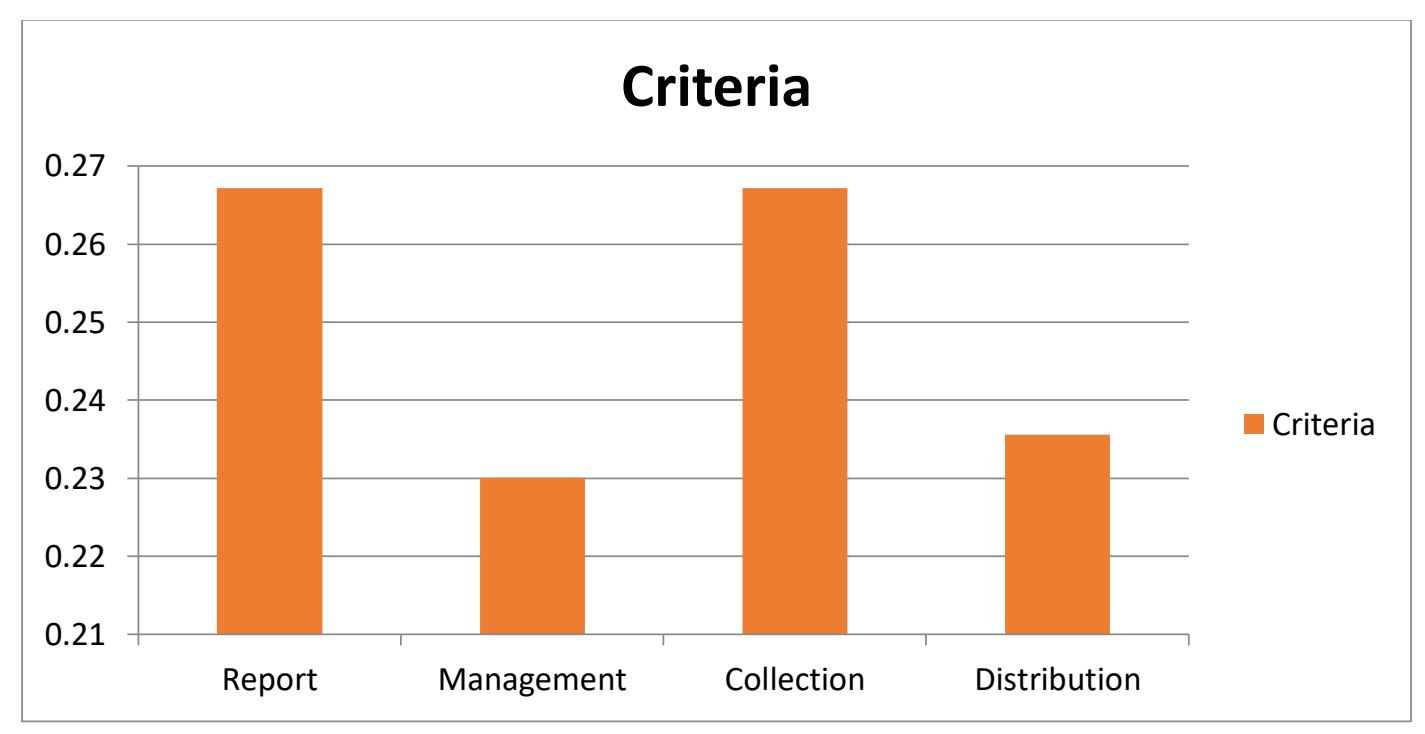

Source: Author's Own

Figure 4.2. Assessment of Criteria

Reporting of zakat is important as it represents the professionalism, transparency, trust and responsibility of amil institutions in managing, collecting and distributing zakat fund from and to the society. Therefore, the provision of audited public financial reports both from internal and external auditors on regular basis play an important role of the performance of amil institutions. Reporting of zakat can build trust from the public and other zakat stakeholders that in the long run can positively influence the institutions performance. Once trust is built, the collection and distribution of zakat can be improved.
Following zakat reporting, the collection of zakat is also important as it can directly influence on how much zakat fund can be distributed to the zakat recipients. The more zakat fund is collected, the bigger is the opportunity of amil zakat to disburse it to the society. The high growth of zakat collection represents the high awareness of muzakki to fulfill their zakat obligation in accordance with the shariah. Besides, this can also show the high trust that amil institutions get from the public.

In the third place, the distribution is also crucial as it plays as the main indicator 
determining the success of zakat development. Compared with the sequence and arrangement in the holy Quran, the verse related to zakat distribution (Quran 9: 60) appears earlier than the verse regarding zakat collection (Quran 9: 103). As AlQaradawi (2002) affirms that the basic objective of zakat is to solve tricky social problems such as poverty, unemployment, natural catastrophes, indebtedness and inequitable income distribution, the distribution of zakat hence should become top agenda. Kaslam (2007) argues that it is the duty of the responsible zakat-officials to be, at all times, fully aware of the persons under their jurisdiction, who are deserving of receiving zakat assistance. Zakat should be regarded as an instrument for improving social well-being.

Lastly, although the management of zakat has the least portion in the indicators of amil institution performance, the amil institutions should still provide standard operational procedures of zakat management, strategic planning, ISO certification or quality management and the annual working program in order to aim the good amil governance in a more comprehensive way.

\section{ASSESSMENT OF ALTERNATIVES}

In terms of alternatives, Table 4.2 and Figure 4.3 below depict the prioritization of the strategies to strengthen the role of amil institutions with respect to the four aforesaid elements. It can be observed that the optimization of zakat program becomes the first top strategy that should be implemented. This can be realized through variety of zakat distribution and empowerment program that should not only confine to the consumptive-based program, but also the productive-based program. Hafidhuddin et al (2015) opine that zakat program should be based on the Zakat Management No. 23/2011 chapter 1 article 2. In this regard, zakat program must be in accordance with the shariah, trusted, beneficial, just, integrated and accountable.

In the current time, zakat has been distributed to around 2.8 million beneficiaries through variation of distribution programs (Indonesia Zakat and Development Report, 2011). Around two third of zakat collection is allocated for consumptive-based programs, while the remaining one third is distributed for productive-based programs.

The former specifically aims at helping the beneficiaries without having long term objective to realize the independence of the mustahik. The latter aspires to achieve the financial independent status of the beneficiaries, which in the long-run they are expected to become zakat payers. Therefore, productive-based program should become the top priority for the zakat distribution program.

Strengthening the information and technology (IT) system of zakat places the second rank of the alternatives strategies needed to strengthen the role of amil institutions. The strong IT system can support the efficiency and effectiveness of amil function in managing zakat as a system as whole. It may reduce operational and other unnecessary costs as it improves the reporting, collection, distribution and management system. 
Table 4.2. Assessment of Alternatives

\begin{tabular}{lccccc}
\hline \multicolumn{1}{c}{ Alternatives } & Respondent & Respondent & $\begin{array}{c}\text { Respondent } \\
3\end{array}$ & Average & Rank \\
& 1 & 2 & & \\
\hline $\begin{array}{l}\text { Database of Muzaki and } \\
\text { Mustahik }\end{array}$ & 0.13113 & 0.12494 & 0.16435 & 0.14014 & 4 \\
$\begin{array}{l}\text { Optimization of Zakat } \\
\text { Program }\end{array}$ & 0.16651 & 0.15379 & 0.19271 & 0.17100 & 1 \\
$\begin{array}{l}\text { Strengthening Regulation } \\
\text { Strengthening Human }\end{array}$ & 0.18778 & 0.14330 & 0.12570 & 0.15226 & 3 \\
$\begin{array}{l}\text { Resources } \\
\text { Synergy between Amil }\end{array}$ & 0.09856 & 0.17267 & 0.08862 & 0.11995 & 6 \\
$\begin{array}{l}\text { Socialization and } \\
\text { Education }\end{array}$ & 0.09925 & 0.09664 & 0.14116 & 0.11235 & 7 \\
Strengthening IT System & 0.18802 & 0.18733 & 0.11795 & 0.16443 & 2 \\
\hline
\end{tabular}

Source: Author's Own

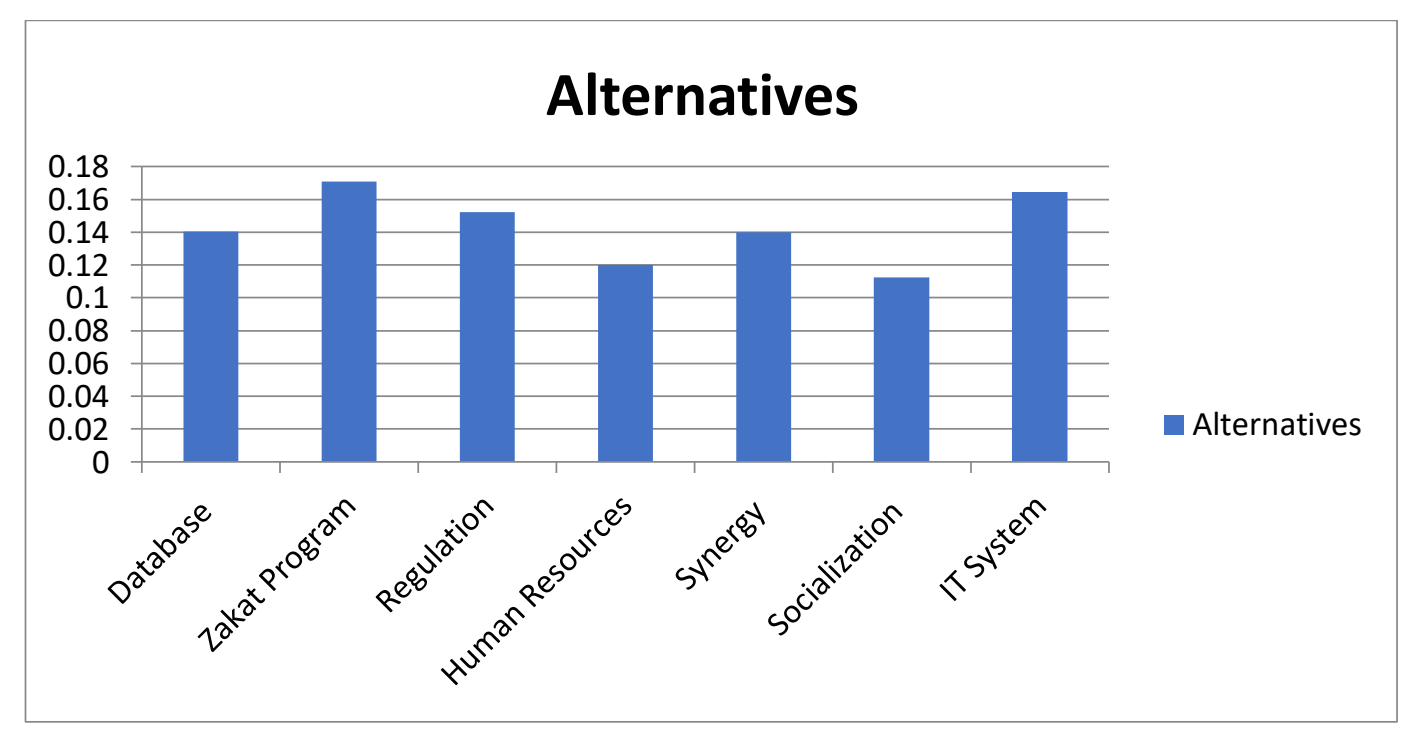

Source: Author's Own

Figure 4.3. Assessment of Alternatives 
In the third rank, strengthening zakat regulation is also important in strengthening the role of amil. Zakat regulation should be strengthened and implemented in order to realize Good Amil Governance. This needs deep and similar understanding from amil institutions, governments and other zakat stakeholders.

Following the regulation of zakat, the alternative of strategy in the fourth rank is the improvement of database of zakat payers and recipients. This can support good management of zakat specifically with respect to the collection and distribution of zakat. The database should cover both potential and actual zakat payers and recipients in each area in order to road map the potential and actual zakat collection and distribution.

Moreover, the synergy between zakat stakeholders is in the fifth place of the alternative strategy. Zakat stakeholders include BAZNAS from the national level to the city and regency level, private zakat institutions, Ministry of Religious Affairs, government at the national and regional level, Islamic social organizations, educational institutions and other institutions at the national and even international level. Hafidhuddin et al (2015) opine that synergy between zakat stakeholders aims at achieving the role of zakat in realizing welfare in the society. Besides, it can also strengthen the brotherhood in Islam in general.

The sixth prioritized strategy is strengthening human resources. This includes improving the quality of human resources in the zakat world to become knowledgeable, professional and trustable as well as to have good attitude (akhlak).

In the last rank, socialization and education should be undertaken specifically that relates to the definition, wisdom, benefit, object, advantage and regulation of zakat. Besides that, the link between zakat and tax should also be included in the zakat campaign. The socialization and education of zakat can improve people's awareness of zakat so that zakat can be accepted and implemented as a system as a whole.

\section{CONCLUSIONS}

As the third pillar of Islam, zakat mainly aims to improve the social and economic well-being of the society. To realize this goal, the role of amil institutions as assigned in the several Quranic verses should be strengthened. This study hence attempts to formulate strategies in strengthening the role of amil institutions based on the judgment of zakat experts and practitioners.

This study constructs amil performance indicators based on the National Zakat Index that consists of collection, distribution, management and reporting of zakat. It is found that among four zakat institutions' indicators, the reporting of zakat shared the highest portion of the important indicators of amil, followed by the collection, distribution and management of zakat.

Besides that, the study also finds that the strategies that needs to be given top priorities in order are optimizing zakat distribution program, strengthening Information and Technology (IT) System, strengthening zakat regulation, improving database of zakat payers and beneficiaries, strengthening the synergy between amil boards, institutions and other zakat stakeholders, strengthening human resources and improving the socialization as well as education pertaining to zakat and the role of zakat board and institutions. 


\section{REFERENCES}

Abdullah, N. \& Yusop, M. (2015) Issues on Zakat and its Poverty Alleviation Goal. In M. Yusop \& N. Abdullah, Zakat and Poverty Alleviation (pp. 3-11). Kuala Lumpur: IIUM Press.

Al-Qaradawi, Y. (1993). Fiqhuz Zakat. Jakarta: Litera AntarNusa.

Al-Qaradawi, Y. (2002). Zakat Role in Curing Social and Economic Malaises. In Kahf, M., Economics of Zakat. Jeddah: IRTI - IDB.

Ascarya. (2011)."The Persistence of Low Profit and Loss Sharing Financing in Islamic Banking: The Case of Indonesia". Review of Indonesian Economic and Business Studies vol.1 LIPI economic research center.

Ayuniyyah, Q. and Shalihati, S. 2011. Factors Affecting Zakat Payment Through Institution of Amil: Case Study of Badan Amil Zakat Nasional (a paper presented at International Zakat Conference held by World Zakat Forum in cooperation with Badan Amil Zakat Nasional, Faculty of Economics and Management Institut Pertanian Bogor, and Ibn Khaldun University on July 19- 21, 2011).

Ayuniyyah, Q. (2011). Factors Affecting Zakat Payment through Institution of Amil: Muzakki's Perspectives Analysis (Case Study of BAZNAS). Jurnal Ekonomi Islam Al-Infaq, Vol. 2 No. 2, September 2011 pp. 49-64, Program Studi Ekonomi Islam FAIUIKA Bogor.

Badan Amil Zakat Nasional. (2017). National Zakat Index. Jakarta: BAZNAS.
Badan Amil Zakat Nasional (2016). Annual Report. Jakarta: BAZNAS.

Beik, I. S. (2013). Economic Role of Zakat in Reducing Poverty and Income Inequality : A Case Study in the Province of DKI Jakarta, Indonesia. Deutschland: LAP Lambert Academic Publishing.

Firdaus, M. Beik, I.S., Irawan, T., \& Juanda, B. (2012). "Economic Estimation and Determinations of Zakat Potential in Indonesia". IRTI Working Paper Series, WP 143307(August). Retrieved from http://www.irti.org/English/Research/ Documents/334.pdf

Hafidhuddin, D., Nasar, M. F., Kustiawan, T., Beik, I. S., \& Hakiem, H. (2015). Fiqh Zakat Indonesia. Jakarta: BAZNAS.

Hafidhuddin, D. and Juwaini, A. (2006) Membangun Peradaban Zakat: Meniti Jalan Kegemilangan Zakat. Jakarta: Institut Manajemen Zakat.

Hafidhuddin, D. (2002). Zakat dalam Perekonomian Modern. Jakarta: Gema Insani Press.

Hasan, Z. (2006). Introduction to Microeconomics: An Islamic Perspective. Kuala Lumpur: Pearson Prentice Hall Peason Malaysia Sdn. Bhd.

Hudaefi, F. A., Beik, I. S., Zaenal, M. H., Choirin, M., Farchatunnisa, H., \& Junari, U. L. (2020). How does zakat institution respond to fintech? Evidence from BAZNAS Indonesia. IJZIP: International Journal of Zakat and Islamic Philanthropy, 2(1), 3340.

Indonesia Zakat and Development Report (2012). Annual Report. Jakarta: IZDR. 
Indonesia Zakat and Development Report (2011). Annual Report. Jakarta: IZDR.

Kaslam, S. (2007) "Governing Zakat as Social Institution: Malaysian Perspective". A paper presented at South East Asia Zakat Conference, Padang.

Rukmana, Y. (2014). Formulasi Strategi Transformasi Pada Lembaga Amil Zakat Nasional Dompet Dhuafa. (Master). Bogor Agricultural University

Saaty, T. L. and Vargas, L. G. 2006. Decision Making with the Analytic Network Process. Economic, Political, Social and Technological Applications with Benefits, Opportunities, Costs and Risks. Springer: RWS Publication, Pittsburgh.

Saaty, T. L. (1999). "Fundamentals of the Analytical Network Process". ISAHP, Kobe Japan, August 12-14.

Shalihati, F. 2010. Analisis Sikap dan Persepsi Muzaki terhadap Badan Amil Zakat Nasional di Kota Jakarta (Master). Bogor Agricultural University.

Syahhatih, S. I. (1989). Penerapan Zakat dalam Dunia Modern. Translator Anshori Umar Sitanggal. Jakarta: Pustaka Dian dan Antar Kota.
Qurroh Ayuniyyah, PhD

Senior Lecturer

Department of Islamic Economics,

Post Graduate School

Bogor Ibn Khaldun University

Jl. KH. Soleh Iskandar Km. 2 Kampus

UIKA Bogor 16162

INDONESIA

qurroh.ayuniyyah@uika-bogor.ac.id

Didin Hafidhuddin

A Kiyai Hajj (Indonesian Ulama - Muslim

Scholar) and a Professor at

Post Graduate School

Bogor Ibn Khaldun University

Jl. KH. Soleh Iskandar Km. 2 Kampus

UIKA Bogor 16162

INDONESIA

hafidhuddin@yahoo.com

Hambari

Lecturer

Faculty of Islamic Studies

Bogor Ibn Khaldun University

Jl. KH. Soleh Iskandar Km. 2 Kampus

UIKA Bogor 16162

INDONESIA

hambari@uika-bogor.ac.id 
International Journal of Zakat Vol. 5(3) 2020 